\title{
Characterization of Novel Genotyping-by-sequencing (GBS)- based Simple Sequence Repeats (SSRs) and Their Application for Population Genomics of Capoeta Aculeata (Valenciennes, 1844)
}

\author{
Habibollah Gandomkar ( $\square$ gandomkar.habib@gmail.com ) \\ Iranian Fisheries Research Organization \\ Seyed Pezhman Hosseini Shekarabi \\ Islamic Azad University \\ Hossein Ali Abdolhay \\ Iranian Fisheries Research Organization \\ Sajad Nazari \\ Iranian Fisheries Research Organization \\ Mehdi Shamsaei Mehrjan \\ Islamic Azad University
}

\section{Research Article}

Keywords: Capoeta aculeata, microsatellite markers, next generation sequencing (NGS), Genetic structure

Posted Date: May 26th, 2021

DOI: https://doi.org/10.21203/rs.3.rs-514326/v1

License: (우 (i) This work is licensed under a Creative Commons Attribution 4.0 International License. Read Full License

Version of Record: A version of this preprint was published at Molecular Biology Reports on August 22nd, 2021. See the published version at https://doi.org/10.1007/s11033-021-06653-x. 


\section{Abstract}

The species Capoeta aculeata (Valenciennes, 1844) is one of the most important freshwater species endemic to Iran. However, the investigation of a population genetic structure of this species is limited by the low number of molecular markers currently described. In this study, we implemented next generation sequencing technology to identify polymorphic microsatellite markers and investigate the population genetic structure of $C$. aculeata sampled from three geographical sites in Iran. We sequenced 60 individuals from three populations occurring in the Zagros basin. We characterized and developed 36 novel polymorphic microsatellite markers and these loci were examined in 120 individuals from three populations occurring in the Zagros basin. The average number of alleles per locus varied from 1.7 to 16 . (average $=7.89$ ). The results showed that, the polymorphism information content $(\mathrm{PCl})$ of these SSR loci varied from 0.254 to 0.888 . The observed heterozygosity $(\mathrm{Ho})$ per locus ranged from 0.170 to 0.881 , while the expected heterozygosity $(\mathrm{He})$ per locus was from 0.170 to 0.881 . Among these SSR loci, 20 loci deviated significantly from the Hardy-Weinberg equilibrium after Bonferroni correction $(p<0.05)$. These microsatellite markers could provide a valuable tool for future population and conservation genetics studies of $C$. aculeate populations and other closely related species.

\section{Introduction}

The genus Capoeta is a herbivorous cyprinid genus and highly diversified with 14 species and widely distributed in water bodies of Western Iran. Kohgiluyeh and Boyer-Ahmad Province in the southwest part of Iran is a region with high number of endemism in some freshwater fish species including Capoeta aculeata (Valenciennes, 1844) (Zareian et al., 2016). However, populations of this species have experienced significant declines over the last 20 years, due primarily to habitat loss and fragmentation caused by water storage and land clearing. The previous phylogenetic and phylogeographic studies found that populations of $\mathrm{C}$. aculeata are different from the others (Freyhof et al., 2014).

Simple sequence repeat (SSR), also known as microsatellite markers are highly variable DNA sequences, distributed throughout eukaryotic genomes (Sunnucks, 2000; Zane et al., 2002). Given its co-dominant inheritance, bi-parental mode of inheritance, polymerase chain reaction (PCR)-based, high amplification success rate and levels of polymorphism, microsatellite markers have been used in a wide range of applications in population genetics, molecular ecology, conservation genetics and quantitative trait loci (QTL) identification studies (Chang et al., 2009; Xue et al., 2014; Horner et al., 2016; Montanari et al., 2016). Nevertheless, the conventiona/ methods for developing SSR markers are believed to be the key element which limits the application of microsatellite markers due to they are expensive, low efficiency, laborious and time-consuming (Jia et al., 2013; Perina et al., 2016). In fact, SSR markers are tremendously effective tools in population genetic studies because they might reveal the distinct population Segments (DPSs) even in fine-scale genetic structure studies. Until now, microsatellite loci have not been reported in this species (Gandomkar et al., 2020).

The major advantage of Next generation sequencing (NGS) technique is their ability to produce large amounts of sequence data and it can provide wide genetic information of simple sequence repeat (SSR) or microsatellite loci. Restriction-site associated DNA sequencing (RAD-seq) is a powerful tool to develop microsatellite and single nucleotide polymorphism (SNP) markers, which uses Illumina next-generation sequencing (NGS) platforms to discover informative volume of independent markers in a lot of specimens at the same time (Feng et al. 2014; Xiao et al. 2018; Khoshkholgh and Nazari, 2020).

The reads created by RAD-seq can be grouped according to the enzyme recognition sequence, so this procedure could develop the accuracy and precision of contigs assembly, and consistently expand the success rate of polymorphic microsatellite markers development (Wei et al. 2014; Ewers-Saucedo et al. 2016). In comparison with other techniques, restriction site-associated DNA sequencing (RAD-seq) gradually become the most promising method and can give genomewide genotypic and sequence data adjacent to single restriction enzyme cut sites and generate reduced representation genomic libraries (Davey et al. 2011; Zhou et al. 2017). Recently, the characterization and development of RAD-seq have been used to report microsatellite markers in many cyprinid species, such as Ctenopharyngodon Idella (Yu et al. 2014), Schizothorax prenanti (Luo et al. 2016) and Xenocypris argentea (Peng et al. 2018). However, the genetic background of $C$. aculeata is limited and no microsatellite locus has been characterized for this species. In this study, RAD-seq was used to isolate and develop the first resource of microsatellite loci for $C$. aculeata from Iran. 


\section{Materials And Methods}

In this study, fin clips of 120 individuals were collected from three wild $C$. aculeata populations inhabiting the Beshar, Khersan, Maroun rivers in Kohgiluyeh and Boyer-Ahmad Province in Iran (Fig. 1, Table 1). All procedures were approved by the Committee on Animal Care and Use, and Committee on the Ethics of Animal Experiments of Agricultural Research, Education and Extension Organization (AREEO) and Islamic Azad University. The modified method (Nazari et al. 2016) was used to extract genomic DNA using the commercial DN-easy blood and tissue kit (Qiagen ${ }^{\mathrm{T}}{ }^{\mathrm{M}}$, Germany) following the manufacturer's instructions. The quality of DNA was assessed using a Nanodrop spectrophotometer (Nanodrop ND1000) and 1\% agarose-gel electrophoresis, after which DNA concentration of each sample was diluted to $100 \mathrm{ng}$ in a $100 \mu \mathrm{L}$ volume and stored at $-20^{\circ} \mathrm{C}$ (Khoshkholgh and Nazari, 2019).

\section{Screening of microsatellite loci by PCR}

DNA was isolated and purified from fin clips (about 30-50 mg) or the muscle samples of each fish. DNA was extracted using the commercial DN-easy blood and tissue kit (Qiagen ${ }^{\mathrm{TM}}$, Germany) following the manufacturer's instructions and standardized the final DNA concentration of each sample to $100 \mathrm{ng}$ in a $10 \mu \mathrm{L}$ volume (Nazari et al. 2016 ). DNA Extraction was examined for concentration using spectrophotometer (Nanodrop ND1000) and standardized to a specific concentration (for example, $100 \mathrm{ng} / \mu \mathrm{l}$ for Polymerase Chain Reaction (PCR)). Quality and concentrations of DNA samples were proved on 1.0\% agarose gels and evaluated using a Nanodrop 1000 spectrophotometer.

\section{RAD library construction}

RAD library preparation was carried out following the protocol of (Wang et al. 2016). Briefly, genomic DNA from each individual was digested for $2 \mathrm{~h}$ at $37^{\circ} \mathrm{C}$ in a $40 \mu \mathrm{L}$ reaction at specific sites with EcoRI-HF restriction enzymes according to the RAD protocol (Bian et al. 2018). Adapter P1 containing individual-specific nucleotide barcodes was ligated to the digested product. Ligation reaction was performed in a $40 \mu \mathrm{L}$ volume along with $5 \mu \mathrm{L}$ of ligation buffer, $0.85 \mu \mathrm{L}$ of $\mathrm{P} 1$ adapter, and 300 units of ligase for $2 \mathrm{~h}$ at $25^{\circ} \mathrm{C}$. DNA was subsequently ligated to a second adapter (P2), which contains T overhangs. The ligated materials were then pooled, purified, eluted and subjected to PCR enrichment. Total genomic DNA samples were sheared to fragment DNA to an average size of $350 \mathrm{bp}$ and a pool of adapter-ligated molecules with random, variable ends was generated. DNA fragments with lengths of 250-500 bp were isolated using the Qiagen Min Elute Gel Extraction kit (Qiagen ${ }^{\mathrm{TM}}$, Germany). The libraries constructed were sequenced on the Illumina HiSeq 4000 platform (BGI, China) using 150 bp paired-end reads.

The quality control of the raw sequences was initially evaluated with the program FastQC (Babraham Bioinformatics) (Andrews 2010). Reads were controlled with Cutadapt to eliminate potential ligated materials of Illumina adapters, permitting a $10 \%$ mismatch rate in the adapter sequence (Martin 2011). During this process, the programs process_radtags module and clone_filter from the software Stacks version 2.52 (http://catchenlab.life.illin ois.edu/stacks/) were usedto demultiplex data and trim adapter sequences and remove over-represented sequences, respectively (Catchen et al. 2013; Rochette et al. 2019). To avoid low-quality reads with artificial bias, the following thresholds were set ( $\mathrm{Li}$ and Godzik 2006): reads with adapter contamination were removed; reads with $\geq 10 \%$ unidentified nucleotides were removed; reads with $>50 \%$ bases having phred quality $<5$ were removed; putative duplication reads generated by PCR amplification in library construction were discarded; reads were checked for presence of the

partial 5 bp EcoR/motif (AATTC). De novo assembly was performed using software SPAdes (Bankevich et al. 2012). The contigs shorter than $100 \mathrm{bp}$ were removed from the assembly. To evaluate the quality of assembly, the reads involved in alignment were re-mapped onto the assembled genome using BWAprogram (version 0.7.17) (Li and Durbin, 2009).

All clean sequences were aligned to the reference assembly using BWAprogram. Microsatellite motif repeats of mono to hexanucleotide microsatellites were identified from the assembled genome using MIcroSAtellite identification tool (MISA) (http://pgrc.ipk-gater slebe n.de/misa/). The following criteria of motifs were required to be met: at least 10 repetitive motifs for mononucleotide, 6 repetitive motifs for di-nucleotide, and 5 repetitive motifs for tri- to hexa-nucleotide. The number of microsatellite loci, repeat motifs, number of repeats, motifs sequence length, repeat type, start and end location of the repeat sequence, and microsatellite sequence, were analyzed using MISA. 
A total of 36 polymorphic loci were selected for validation by PCR. Polymerase chain reaction (PCR) reactions were performed in a final volume of $25 \mu \mathrm{L}$ consisting of $1.2 \mu \mathrm{L}$ of template DNA (100 ng), $2.5 \mu \mathrm{L}$ of 10xPCR buffer, $2.5 \mu \mathrm{L}$ of Mg2+ $(20 \mathrm{mM}), 0.85 \mu \mathrm{L}$ of dNTP mixture ( $2.5 \mathrm{mM}$ each), $0.30 \mu \mathrm{L}$ of each primer (10 pmol/ $\mu \mathrm{l}), 17.35 \mu \mathrm{L}$ of ddH2O, and $0.3 \mu \mathrm{L}$ of $1 \mathrm{U} / \mu \mathrm{l} \mathrm{Taq} \mathrm{DNA}$ polymerase (Qiagen ${ }^{\mathrm{T}}$, Germany). Amplified products were checked on $1 \%$ agarose gel electrophoresis and sequenced using $\mathrm{ABI}$ Prism 3730 automated DNA analyzer (Applied Biosystems). The PCR amplification procedure was performed in a thermal cycler (Bio-Rad, USA) using following program: first denaturation $94^{\circ} \mathrm{C}, 30 \mathrm{~s}$, one cycle; denaturation $94^{\circ} \mathrm{C}, 30 \mathrm{~s}, 12$ cycles; a specified annealing temperature for each primer pair for $30 \mathrm{~s}, 60 \mathrm{~s}, 12$ cycles; then the products were extended at $72{ }^{\circ} \mathrm{C}$ for 7 min (for annealing temperatures of each primer pair, see Table 3). The PCR products were electrophoresed on $1.2 \%$ agarose gels, stained with ethidium bromide followed by visualization under UV light. SSR loci with single bands were chosen as candidates for additiona/ validation.

\section{Validationof microsatellite polymorphism}

For validated SSR loci, each of the selected primer sequences was validated with 120 single individual of $C$. aculeata from three sampling locations in Iran. From fragment sizing and reporting, GeneMapper (v4.1) was used to analyze genotype data. The negative controls with nuclease-free sterile water were included in each PCR experiment.

For validated loci, statistics including the number of alleles $(\mathrm{Na})$, the effective number of alleles $(\mathrm{Ne})$, the observed heterozygosity $\left(H_{0}\right)$, expected heterozygosity $\left(H_{E}\right)$ indices and inbreeding coefficient $\left(F_{I S}\right)$ were calculated in GenAlex v6.5 (Peakall and Smouse 2012). The Hardy-Weinberg distribution (HWE) with Bonferroni correction was estimated at the population level using Arlequin v3.0 (Excoffier 2005). The inbreeding coefficient index $\left(F_{I S}\right)$ and the polymorphism information content (PIC) were estimated using Genepop V4.7 (Rousset 2008).

\section{Results}

In the present study, the total GBS raw reads varied from 11.4 million to 22.38 million, with total raw nucleotides ranging from $0.93 \mathrm{~Gb}$ to $2.96 \mathrm{~Gb}$. GBS sequence analysis and microsatellite mining were performed using a modified GBS analysis workflow without using a reference genome (Fig 2). After filtering low-quality reads and reads that lacked enzyme cutting sites by the process_radtags component of Stacks v1.39 software, the total number of clean reads kept in the libraries varied from 10.81 to 21.74 million, with an average of 15.72 million. The summary of sequencing reads generated for 30 samples of $C$. aculeata were listed in Table 2.

Of the 15,476 sequences, 16,706 microsatellite loci were found by MISA in C. aculeata genome sequences. The number of 926 sequences contains more than one microsatellite. Among the number of microsatellite loci, dinucleotide repeats were the most abundant $(6843,51.91 \%)$, followed by trinucleotide repeats $(2991,22.69 \%)$, mononucleotide repeats $(2756,20.91 \%)$ tetranucleotide repeats $(478,3.62 \%)$, pentanucleotide repeats $(94,0.71 \%)$, and hexanucleotide repeats $(18,0.13 \%)$.

In the present study, the average of the allele numbers inspected at each locus varied between 1.7 for locus Ca04 to 16 for locus Ca25 (Table 2). The results showed that, the polymorphism information content (PCl) of these SSR loci varied from 0.254 to 0.888 . The observed heterozygosity $(H o)$ per locus ranged from 0.170 to 0.881 , while the expected heterozygosity $(H e)$ per locus was from 0.213 to 0.884 . The final set of all microsatellite loci were most informative (PIC > 0.50). Across all samples, 20 SSR loci showed significant deviations from the Hardy-Weinberg equilibrium after Bonferroni correction, $(p<0.05)($ Table 2).

\section{Discussion}

For non-model organisms, microsatellite loci were generally identified by $5 \rrbracket$ anchor PCR (Ling et al. 2013), transcriptome sequence analysis (Ariede et al. 2018; Han et al. 2018), and microsatellite library screening (Bazsalovicsová et al. 2018) and development of microsatellite loci through cross-species amplification of closely related species (Gravley et al. 2018). In the present study, RAD-seq method was used for isolating microsatellite loci in C. aculeata. In contrast with conventional approaches, RAD-seq approach is considered to be faster and profitable. Furthermore, this method can produce a large number of microsatellite arkers for one time (Peng et al. 2018; Xiao et al. 2018). 
Population structure genetic is very important for the sustainability of many species (Khoshkholgh and Nazari, 2019).

Conservation management plans with no prior information of the genetic background could result in disturbance to the genetic structure with adverse effects on the gene pools of wild populations (Khoshkholgh and Nazari, 2020). Until now, the microsatellite loci have not been carefully developed for $\mathrm{C}$. aculeata which has posed a serious obstacle to conservation and management of this species (Gandomkar et al., 2020). The current study detected 16,706 microsatellite markers in C. aculeata genome using MISA, which accounted for $2.12 \%$ of the total genome sequence. The relative abundance of microsatellite sequences was calculated at 1.16 loci per $\mathrm{kb}$ of $\mathrm{C}$. aculeata genomes. In general, the frequencies of microsatellite loci are expected to decrease with increasing repeat length due to longer repeats have a higher possibility of being mutated. (Pathak et al., 2013), and this tendency has been identified in many organisms (Guichoux et al., 2011; Zalapa et al., 2012; Ma et al., 2013 ) . In summary, this is the first report of SSR loci in $C$. aculeate developed using RAD-seq and therefore these SSR markers would provide an invaluable resource for population genetics and natural resource conservation in $C$. aculeata.

\section{Declarations}

\section{Acknowledgements}

This work was supported by the Research Fund for the department of fisheries science of the Islamic Azad University of Tehran, Iran.

\section{Author contributions}

Habibollah Gandomkar made the literature, sample collection, material preparation. Seyed Pezhman Hosseini Shekarabi has major contribution to the preliminary study design and interpretation of data. The first draft of the manuscript was written by Hossein Ali Abdolhay. Sajad Nazari designed the experiment, institutional support and supervision of the preliminary experiment and made the data analysis. Mehdi Shamsaei Mehrjan has significant contributions to the laboratory work and interpretation of the results. All authors read and approved the final manuscript.

\section{*Consent to Participate (Ethics)}

Informed consent was obtained from all individual participants included in the study.

\section{*Consent to Publish (Ethics)}

The participant has consented to the submission of the report to the journal.

\section{Availability of data and material (data transparency)}

The datasets generated are available from the corresponding author upon request.

\section{Compliance with ethical standards}

Conflict of interest: The authors declare that they have no conflict of interest.

Informed consent: This research does not involve humans and therefore informed consents are not applicable.

\section{Ethical approval}

The main research project researcher of this work was approved for animal ethics by Iranian Fisheries Sciences Research Institute (IFSRI) for scientific purposes development, Iran. All applicable guidelines for the care and use of animals were followed by the authors. The experiment was approved for Animal Welfare by the Institutional Animal Welfare Committee of Agricultural Research, Education and Extension Organization (AREEO), Iran.

\section{References}


Andrews S (2010) FastQC: a quality control tool for high throughput sequence data.

Ariede, R. B., Freitas, M. V., Hata, M. E., Matrochirico-Filho, V. A., Utsunomia, R., Mendonça, F. F., et al. (2018). Development of microsatellite markers using next-generation sequencing for the fish Colossoma macropomum. Mol. Biol. Rep. 45, 9-18. doi: 10.1007/s11033-017-4134-z

Bankevich A, Nurk S, Antipov D, Gurevich AA, Dvorkin M, Kulikov AS, Lesin VM, Nikolenko SI, Pham S, Prjibelski AD, Pyshkin AV, Sirotkin AV, Vyahhi N, Tesler G, Alekseyev MA, Pevzner PA (2012) SPAdes: a new genome assembly algorithm and its applications to single-cell sequencing. J Comput Biol 19:455-477

Bazsalovicsová, E.; Koleni cová, A.; Králová-Hromadová, I.; Minárik, G.; Šoltys, K.; Kuchta, R.; Štefka, J. Development of microsatellite loci in zoonotic tapeworm Dibothriocephalus latus (Linnaeus, 1758), Lühe, 1899 (syn. Diphyllobothrium latum) using microsatellite library screening. Mol. Biochem. Parasitol. 2018, 225, 1-3.

Catchen J P, Hohenlohe SB, Amores A, Cresko W (2013) Stacks: an analysis tool set for population genomics. Mol Ecol 22(11):3124-3140.

Chang Y, Feng Z, Yu J, Ding J (2009) Genetic variability analysis in five populations of the sea cucumber Stichopus (Apostichopus) japonicus from China, Russia, South Korea and Japan as revealed by microsatellite markers. Mar Ecol 30:455461.

Cheng J, Hui M, Li, Y., Sha, Z. (2020) Genomic evidence of population genetic differentiation in deep-sea squat lobster Shinkaia crosnieri (crustacea: Decapoda: Anomura) from Northwestern Pacific hydrothermal vent and cold seep. Deep-Sea Res Part I 156, https://doi.org/10.1016/j.dsr.2019.103188.

Danecek P, Auton A, Abecasis G et al (2011) The variant call format and VCFtools. Bioinformatics 27:2156-2158.

Davey JW, Hohenlohe PA, Etter PD, Boone JQ, Catchen JM, Blaxter ML (2011) Genome-wide genetic marker discovery and genotyping using next-generation sequencing. Nat Rev Genet 12:499-510

Duan, C. X., Li, D. D., Sun, S. L., Wang, X. M. \& Zhu, Z. D. (2014) Rapid development of microsatellite markers for Callosobruchus chinensis using illumina paired-end sequencing. PLOS ONE. 9, e95458.

Ewers-Saucedo, C., Zardus, J. D. \& Wares, J. P. (2016) Microsatellite loci discovery from next-generation sequencing data and loci characterization in the epizoic barnacle Chelonibia testudinaria (Linnaeus, 1758). PeerJ. 4, e2019.

Excoffier L (2005) Arlequin (version 3.0): an integrated software package for population genetics data analysis. Evol Bioinform. https ://doi.org/10.1143/JJAP.34.L418

Feng N, Ma H, Ma C et al (2014) Characterization of 40 single nucleotide polymorphism (SNP) via T m-shift assay in the mud crab (Scylla paramamosain). Mol Biol Rep 41:5467-5471. https ://doi. org/10.1007/s1103 3-014-3420-2

Freyhof J, EsmaeiliHR, Sayyadzadeh G, GeigerM(2014) Review of the crested loaches of the genus Paracobitis from Iran and Iraq with the description of four new species (Teleostei:Nemacheilidae). Ichthyol Explor Freshw 25(1):11-38

Gandomkar H, Shekarabi SPH, Abdolhay HA, Nazari S, Mehrjan MS. 2020. Genetic structure of the Capoeta aculeata populations inferred from microsatellite DNA loci. Biodiversitas 21: 4565-4570. https://doi.org/10.13057/biodiv/d211014

Gravley MC, Pierson BJ, Sage GK, Ramey AM, Talbot SL (2018) DNA microsatellite markers for northern fulmar (Fulmaris glacialis) and cross-species amplifcation in select seabird species, Alaska 2018. U.S. Geological Survey data release. https://doi. org/10.5066/P9KWA9VZ

Guichoux E, Lagache L, Wagner S, Chaumeil P, Léger P, Lepais O, Lepoittevin C, Malausa T, Revardel E, Salin F, Petit RJ (2011) Current trends in microsatellite genotyping. Mol Ecol Resour 11:591-611 
Han, Z., Xiao, S., Li, W., Ye, K., and Wang, Z. Y. (2018). The identification of growth, immune related genes and marker discovery through transcriptome in the yellow drum (Nibea albiflora). Genes Genomics 40, 881-891. doi: 10.1007/s13258-018-0697-x

Jia, S. W., Liu, P., Li, J., Li, J. T. Pan, L. Q. (2013) Isolation and characterization of polymorphic microsatellite loci in the ridgetail white prawn Exopalaemon carinicauda. Genet. Mol. Res. 12, 2816-2820.

Khoshkholgh M. Nazari S. (2020) Characterization of single nucleotide polymorphism markers for the narrow-clawed crayfish Pontastacus leptodactylus (Eschscholtz, 1823) based on RAD sequencing. Conservation Genet Resour . https://doi.org/10.1007/s12686-020-01154-8

Khoshkholgh, M and Nazari, S., (2019) The genetic diversity and differentiation of narrow-clawed crayfish Pontastacus leptodactylus (Eschscholtz, 1823) (Decapoda: Astacidea: Astacidae) in the Caspian Sea Basin, Iran as determined with mitochondrial and microsatellite DNA markers, J Crust Bio/39 (2): 112-120.

Li H, Durbin R (2009) Fast and accurate short read alignment with Burrows-Wheeler Transform. Bioinformatics 25:1754-1760

Ling, L.P., Adibah, A.B., Tan, S.G. et al. (2013) Isolation by the 5' anchored PCR technique and characterization of eighteen microsatellite loci in horseshoe crab (Tachypleus gigas). J Genet 92, 101-104. https://doi.org/10.1007/s12041-011-0115-5

Luo H, Ye H, Xiao S-J et al (2016) Development of SNP markers associated with immune-related genes of Schizothorax prenanti. Conserv Genet Resour 8:223-226. https ://doi.org/10.1007/s12686-016-0539-6.

Ma H, Zou X, Ji X, Ma C, Lu J, Jiang W, Xia L, Li S, Liu Y, Gong Y, Ma L (2013) Discovery and characterization of a first set of polymorphic microsatellite markers in red crab (Charybdis feriatus). J Genet 92:e113-e115

Martin M (2011) Sequencing Reads. EMBnet.journal 17:10-12

Montanari S, Perchepied L, Renault D, Frijters L, Velasco R, Horner M, Gardiner SE, Chagné D, Bus VGM, Durel CE, Malnoy M (2016) A QTL detected in an inter specific pear population confers stable fire blight resistance across different environments and genetic backgrounds. Mol Breeding 36:1-16.

Nazari S, Jafari V, Pourkazemi M, Kolangi Miandare H, Abdolhay H. (2016). Association between myostatin gene (MSTN-1) polymorphism and growth traits in domesticated rainbow trout (Oncorhynchus mykiss). Agri Gene, 1: 109-115.

Pathak RU, Mamillapalli A, Rangaraj N, Kumar RP, Vasanthi D, Mishra K, Mishra RK. (2013) AAGAG repeat RNA is an essential component of nuclear matrix in Drosophila. RNA Biol.10(4):564-71.

Peakall R, Smouse PE (2012) GenAIEx 6.5: genetic analysis in Excel. Population genetic software for teaching and research_an update. Bioinformatics 28:2537-2539.

Peng X, Zhao L, Liu J, Guo X (2018) Development of SNP markers for Xenocypris argentea based on transcriptomics. Conserv Genet Resour 10(4):679-684. https ://doi.org/10.1007/s12686-017-0900-4

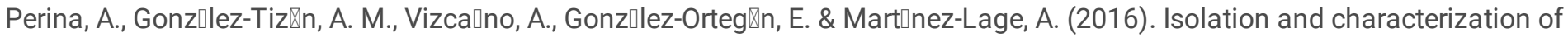
20 polymorphic microsatellite loci in Palaemon serratus and cross-amplification in Palaemon species by 454 pyrosequencing. Conserv.Genet. Resour. 8, 169-196

Rousset F (2008) Genepop'007: a complete re-implementation of the genepop software for windows and linux. Mol Ecol Resour 8:103-106

Sunnucks P (2000) Efficient genetic markers for population biology. Trends Ecol Evol 15:199-203.

Wang S, Liu P, Lv J, Li Y, Cheng T, Zhang L (2016) Serial sequencing of iso-length rad tags for cost-efficient genome-wide profiling of genetic and epigenetic variations. Nat Protoc 11(11):2189-2200. https ://doi.org/10.1038/nprot .2016.133

Page $7 / 15$ 
Wei, N., Bemmels, J. B. \& Dick, C. W. (2014) The effects of read length, quality and quantity on microsatellite discovery and primer development: from Illumina to PacBio. Mol. Ecol. Resour. 14, 953-965.

Xiao M, Hu Q, Zhao Y, Bao F, Cui F, Zheng R (2018) Development of 36 SNP markers in Ophiocephalus argus Cantor base on high throughput sequencing. Conserv Genet Resour 10(1):35-38. https://doi.org/10.1007/s1268 6-017-0757-6

Xue D, Zhang T, Liu J (2014) Microsatellite evidence for high frequency of multiple paternity in the marine gastropod Rapana venosa. PloS ONE 9:e86508.

Yu L, Bai J, Cao T et al (2014) Genetic variability and relationships among six grass carp Ctenopharyngodon idella populations in China estimated using EST-SNP markers. Fish Sci 80:475-481. https ://doi.org/10.1007/s1256 2-014-0709-y

Zalapa JE, Cuevas H, Zhu H, Steffan S, Senalik D, Zeldin E, McCown B, Harbut R, Simon P (2012) Using next-generation sequencing approaches to isolate simple sequence repeat (SSR) loci in the plant sciences. Am J Bot 99:193-208

Zane L, Bargelloni L, Patarnello T (2002) Strategies for microsatellite isolation: a review. Mol Ecol 11:1-16.

Zareian, H., Esmaeili, H. R., Freyhof, J., 2016. Capoeta anamisensis, a new species from the Minab and Hasan Langhi River drainages in Iran (Teleostei: Cyprinidae). Zootaxa 4083, 126-142.

Zerbino DR, Birney E (2008) Velvet: algorithms for de novo short read assembly using de Bruijn graphs. Genome Res 18:821-829.

Zhou J, Zhou B, Li Q et al (2017) Isolation and characterization of 33 EST-SNP markers in Schizothorax prenanti. Conserv Genet Resour 10:205-207. https ://doi.org/10.1007/s1268 6-017-0799-9

\section{Tables}

Table 1: $C$. aculeata samples collected for population genetic analysis. Sampling localities, numbers (see Fig. 1), and number of individuals sampled $(n)$

\begin{tabular}{|ll|}
\hline Region & $n$ \\
\hline Beshar River & 40 \\
\hline Khersan River & 40 \\
\hline Maroun River & 40 \\
\hline Total & 120 \\
\hline
\end{tabular}

Table 2: Description of 36 microsatellite markers in Capoeta aculeata (Valenciennes, 1844) ( $F=$ forward; $R=$ reverse) 


\begin{tabular}{|c|c|c|c|c|c|c|c|c|c|c|}
\hline Name & Primer sequence ( $F$ and $\left.\mathrm{R}, 5^{\prime}-3^{\prime}\right)$ & $\begin{array}{l}\text { Allele } \\
\text { size } \\
\text { (bp) }\end{array}$ & $\begin{array}{l}\text { Repeat } \\
\text { motif }\end{array}$ & $\mathbf{N}_{\mathbf{A}}$ & $\begin{array}{l}\text { TM } \\
\text { (C) }\end{array}$ & $\mathrm{H}_{0}$ & $\mathrm{H}_{\mathrm{E}}$ & $\mathrm{F}_{\mathrm{IS}}$ & PIC & PHWE \\
\hline \multirow[t]{2}{*}{$\mathrm{Ca} 01$} & F: GGCGAACTTGTCTGAGTAAC & \multirow{2}{*}{$\begin{array}{l}202- \\
206\end{array}$} & \multirow[t]{2}{*}{ (ATT) 8} & \multirow[t]{2}{*}{3.8} & \multirow[t]{2}{*}{54} & \multirow[t]{2}{*}{0.318} & \multirow[t]{2}{*}{0.432} & \multirow[t]{2}{*}{0.275} & \multirow[t]{2}{*}{0.635} & \multirow[t]{2}{*}{0.295} \\
\hline & R: GCATTGCAGATTCCAATA & & & & & & & & & \\
\hline \multirow[t]{2}{*}{$\mathrm{CaO2}$} & F: CTCATTCCTTGGACTTGA & \multirow{2}{*}{$\begin{array}{l}228- \\
238\end{array}$} & \multirow[t]{2}{*}{$(\mathrm{GAT}) 9$} & \multirow[t]{2}{*}{4.3} & \multirow[t]{2}{*}{56} & \multirow[t]{2}{*}{0.854} & \multirow[t]{2}{*}{0.879} & \multirow[t]{2}{*}{-0.028} & \multirow[t]{2}{*}{0.672} & \multirow[t]{2}{*}{$0.000 *$} \\
\hline & R: CGTGCATAGATCCCATGCA & & & & & & & & & \\
\hline \multirow[t]{2}{*}{$\mathrm{CaO3}$} & F: AGCTGGCTTGGGAAGCTG & \multirow{2}{*}{$\begin{array}{l}142- \\
164\end{array}$} & \multirow[t]{2}{*}{$(\mathrm{CTT}) 4$} & \multirow[t]{2}{*}{6.8} & \multirow[t]{2}{*}{56} & \multirow[t]{2}{*}{0.722} & \multirow[t]{2}{*}{0.745} & \multirow[t]{2}{*}{-0.048} & \multirow[t]{2}{*}{0.254} & 0.926 \\
\hline & R: AGCGGTAGTAGTGAGTACTC & & & & & & & & & \\
\hline $\mathrm{CaO4}$ & F: TCTGCTAAGCACATCTACAGA & $98-$ & (CGCT)4 & 1.7 & 55 & 0.212 & 0.268 & -0.214 & 0.701 & $0.000 *$ \\
\hline & R: GTCTGTCTCGCTTTCAGTCTC & & & & & & & & & \\
\hline $\mathrm{Ca05}$ & $\begin{array}{l}\text { F: } \\
\text { TGTACAGTATGTCGTCGTCTCA }\end{array}$ & $\begin{array}{l}274- \\
298\end{array}$ & $(\mathrm{GAT}) 7$ & 3.4 & 56 & 0.852 & 0.867 & 0.086 & 0.504 & $0.000 *$ \\
\hline & R: AGTGTTAGCGTTCGTAAGGG & & & & & & & & & \\
\hline $\mathrm{CaO6}$ & F: GCGTAGTTACGCGTTAGTCTA & $94-$ & (AT) 10 & 5 & 58 & 0.766 & 0.784 & -0.116 & 0.869 & 0.122 \\
\hline & R: TGTACGAAGCTAAAGCAGCTG & & & & & & & & & \\
\hline $\mathrm{CaO}$ & F: TTGCTGAGCTTCGTTACGTGA & $100-$ & $(\mathrm{CA}) 7$ & 6.6 & 58 & 0.484 & 0.642 & -0.127 & 0.397 & $0.000 *$ \\
\hline & $\begin{array}{l}\text { R: } \\
\text { CGAAATTCACACTATTCTGACT }\end{array}$ & & & & & & & & & \\
\hline $\mathrm{Ca} 08$ & $\begin{array}{l}\text { F: } \\
\text { ACCGCGCTGATTCTGCTGATCG }\end{array}$ & $\begin{array}{l}192- \\
206\end{array}$ & $(\mathrm{CT}) 8$ & 2.4 & 54 & 0.214 & 0.261 & 0.115 & 0.588 & 0.048 \\
\hline & R: GACCGTCCACTATCTCTCGGA & & & & & & & & & \\
\hline $\mathrm{Ca09}$ & $\begin{array}{l}\text { F: } \\
\text { TAGGAGCCATAGTCTGCTCCTA }\end{array}$ & $\begin{array}{l}242- \\
274\end{array}$ & (TG) 10 & 3.8 & 54 & 0.224 & 0.298 & 0.365 & 0.766 & $0.000 *$ \\
\hline & $\begin{array}{l}\text { R: } \\
\text { ATCGTTACTCAGAAGTGCTCTG }\end{array}$ & & & & & & & & & \\
\hline Ca10 & $\begin{array}{l}\text { F: } \\
\text { TTCGAATAGCTCATCACACCGC }\end{array}$ & $\begin{array}{l}210- \\
242\end{array}$ & (AT) 12 & 12 & 55 & 0.170 & 0.213 & -0.031 & 0.656 & 0.273 \\
\hline & R: TCGTACACACGGAGGACTAGT & & & & & & & & & \\
\hline Ca11 & F: CTTGGTCCTGGCATTGAGTCT & $264-$ & $(\mathrm{CA}) 8$ & 3.2 & 58 & 0.702 & 0.746 & -0.117 & 0.828 & $0.000 *$ \\
\hline & R: ATACTGGGCATGGGGCGTGA & & & & & & & & & \\
\hline Ca12 & $\begin{array}{l}\text { F: } \\
\text { GTAGCTAGTCGACTCGATTACT }\end{array}$ & $\begin{array}{l}202- \\
236\end{array}$ & $(\mathrm{TGA}) 8$ & 2.0 & 58 & 0.318 & 0.389 & 0.488 & 0.771 & $0.000 *$ \\
\hline & R: ATGTAATCATATGTGACGCGA & & & & & & & & & \\
\hline Ca13 & F: CACTTGCGCTAGGATTATGAT & $238-$ & $(\mathrm{TGA}) 8$ & 4.1 & 50 & 0.278 & 0.265 & 0.163 & 0.758 & 0.428 \\
\hline & $\begin{array}{l}\text { R: } \\
\text { GTATCTGAGCTTCTGATCTGTC }\end{array}$ & & & & & & & & & \\
\hline Ca14 & F: ACTGCGTGGTATGGCTGATCC & $210-$ & $(\mathrm{TC}) 7$ & 4.2 & 50 & 0.881 & 0.884 & 0.436 & 0.857 & $0.000 *$ \\
\hline & R: TTCGCGGCGACTATCTAGGGA & & & & & & & & & \\
\hline Ca15 & $\begin{array}{l}\text { F: } \\
\text { GACTACGTGCCCAGGCCAGTAC }\end{array}$ & $\begin{array}{l}246- \\
282\end{array}$ & $(A A G) 6$ & 6.0 & 50 & 0.633 & 0.679 & -0.130 & 0.835 & $0.000 *$ \\
\hline
\end{tabular}




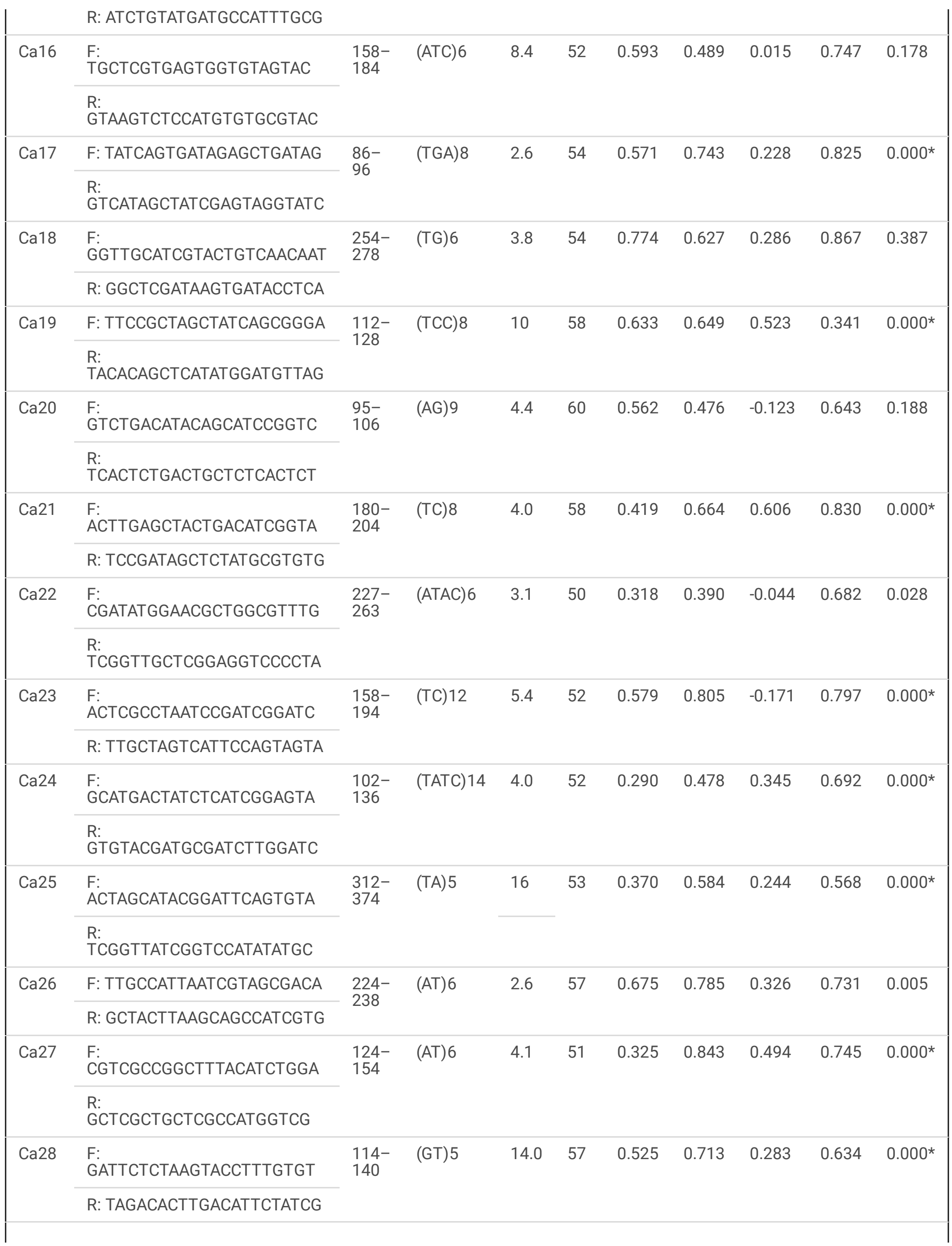




\begin{tabular}{|c|c|c|c|c|c|c|c|c|c|c|}
\hline \multirow[t]{2}{*}{$\mathrm{Ca} 29$} & F: GGTGTCATCTCTCATACTAGC & \multirow{2}{*}{$\begin{array}{l}192- \\
210\end{array}$} & \multirow[t]{2}{*}{ (AT) 5} & \multirow[t]{2}{*}{4.2} & \multirow[t]{2}{*}{58} & \multirow[t]{2}{*}{0.472} & \multirow[t]{2}{*}{0.624} & \multirow{2}{*}{$\overline{0} .283$} & \multirow[t]{2}{*}{0.888} & \multirow[t]{2}{*}{$0.000 *$} \\
\hline & R: CTGTGTCGACATTGCTAGCCG & & & & & & & & & \\
\hline \multirow[t]{2}{*}{ Са30 } & F: TGGTCGGAGTTAACGCTAGC & \multirow{2}{*}{$\begin{array}{l}134- \\
174\end{array}$} & \multirow[t]{2}{*}{$(\mathrm{TA}) 5$} & \multirow[t]{2}{*}{2.0} & \multirow[t]{2}{*}{54} & \multirow[t]{2}{*}{0.551} & \multirow[t]{2}{*}{0.643} & \multirow{2}{*}{$\overline{0} .215$} & \multirow[t]{2}{*}{0.582} & \multirow[t]{2}{*}{0.094} \\
\hline & R: GAGTACGTCGTGGCTCTAACA & & & & & & & & & \\
\hline \multirow[t]{2}{*}{ Ca31 } & F: GGCTAACTACCTGAGGTTATG & \multirow{2}{*}{$\begin{array}{l}142- \\
148\end{array}$} & \multirow[t]{2}{*}{$(\mathrm{CT}) 8$} & \multirow[t]{2}{*}{2.2} & \multirow[t]{2}{*}{53} & \multirow[t]{2}{*}{0.188} & \multirow[t]{2}{*}{0.680} & \multirow{2}{*}{$\overline{0} .549$} & \multirow[t]{2}{*}{0.265} & \multirow[t]{2}{*}{0.343} \\
\hline & R: GTCGGGATATCGCATGTATCA & & & & & & & & & \\
\hline \multirow[t]{2}{*}{ Ca32 } & $\begin{array}{l}\text { F: } \\
\text { AGGTGCATGCACAATCGCGTGC }\end{array}$ & \multirow[t]{2}{*}{$\begin{array}{l}162- \\
168\end{array}$} & \multirow[t]{2}{*}{ (TA) 14} & \multirow[t]{2}{*}{4.4} & \multirow[t]{2}{*}{55} & \multirow[t]{2}{*}{0.207} & 0.642 & $\overline{0} .074$ & 0.468 & 0.288 \\
\hline & R: TAGCTCACTCACCGTCATGAG & & & & & & & & & \\
\hline Са33 & $\begin{array}{l}\text { F: } \\
\text { TCAGAGATGCTCGGATACTGCA }\end{array}$ & $\begin{array}{l}110- \\
131\end{array}$ & $(\mathrm{TG}) 6$ & 5.8 & 56 & 0.625 & 0.685 & -0.495 & 0.726 & 0.009 \\
\hline & $\begin{array}{l}\text { R: } \\
\text { ACCTTGGTGTATTGTATGAGCG }\end{array}$ & & & & & & & & & \\
\hline Ca34 & $\begin{array}{l}\text { F: } \\
\text { GCATACGCAGACTGTATTCGTG }\end{array}$ & $\begin{array}{l}121- \\
154\end{array}$ & $($ AATC) 4 & 9.2 & 55 & 0.567 & 0.802 & 0.368 & 0.387 & $0.000 *$ \\
\hline & $\begin{array}{l}\text { R: } \\
\text { TACAGTCGATGCTAATCATGTC }\end{array}$ & & & & & & & & & \\
\hline Ca35 & $\begin{array}{l}\text { F: } \\
\text { GTCTCACATCAATCGATGTGTG }\end{array}$ & $\begin{array}{l}212- \\
224\end{array}$ & $(A G) 9$ & 4.2 & 56 & 0.438 & 0.442 & 0.166 & 0.368 & 0.098 \\
\hline & R: GAACGGATACTCACTTGAGTC & & & & & & & & & \\
\hline Са36 & $\begin{array}{l}\text { F: } \\
\text { AGTCCTAGTTCATCATCGCTAG }\end{array}$ & $\begin{array}{l}264- \\
268\end{array}$ & (TG) 5 & 4.4 & 57 & 0.231 & 0.587 & 0.216 & 0.467 & $0.000^{*}$ \\
\hline & R: CCGAGTTAGAATGAGCAGTAT & & & & & & & & & \\
\hline
\end{tabular}

Ho: observed heterozygosity, He: expected heterozygosity, $\mathrm{N}_{\mathrm{A}}$ : number of allele, $\mathrm{F}_{\mathrm{IS}}$ : inbreeding coefficient, PIC: polymorphism information content; PHW: P-values for Hardy-Weinberg equilibrium.

*Indicates significant deviation from Hardy-Weinberg Equilibrium after Bonferroni correction

Table 2 Summary of sequencing reads generated for each samples of Capoeta aculeata 


\begin{tabular}{|c|c|c|c|c|c|c|}
\hline Name & $\begin{array}{l}\text { Raw reads } \\
\text { (million) }\end{array}$ & $\begin{array}{l}\text { Raw nucleotides } \\
\text { (Gb) }\end{array}$ & $\begin{array}{l}\text { Clean reads } \\
\text { (million) }\end{array}$ & $\begin{array}{l}\text { Genome } \\
\text { Coverage }\end{array}$ & $\begin{array}{l}\text { Unique } \\
\text { reads }\end{array}$ & $\begin{array}{l}\text { Reads containing } \\
\text { SSRs }\end{array}$ \\
\hline Ca1-kh & 11.42 & 1.25 & 10.81 & 0.62 & 641,025 & 3268 \\
\hline Ca2-kh & 14.32 & 1.58 & 13.35 & 0.68 & 578,246 & 4598 \\
\hline Ca3-kh & 15.65 & 1.45 & 14.56 & 0.64 & 625,268 & 5124 \\
\hline Ca4-kh & 13.44 & 1.42 & 11.30 & 0.59 & 396,795 & 4986 \\
\hline Ca5-kh & 14.65 & 1.74 & 12.48 & 0.74 & 605,436 & 5468 \\
\hline Ca6-kh & 17.21 & 1.69 & 16.19 & 0.69 & 508,294 & 5107 \\
\hline Ca7-kh & 14.24 & 1.42 & 13.28 & 0.57 & 512,346 & 5684 \\
\hline Ca8-kh & 11.86 & 1.24 & 10.67 & 0.52 & 482,247 & 4936 \\
\hline Ca9-kh & 13.12 & 1.43 & 12.49 & 0.54 & 514,345 & 5124 \\
\hline $\begin{array}{l}\text { Ca10- } \\
\text { kh }\end{array}$ & 15.49 & 1.51 & 14.44 & 0.63 & 758,478 & 4719 \\
\hline $\begin{array}{l}\text { Ca11- } \\
\mathrm{Be}\end{array}$ & 11.4 & 1.28 & 11.21 & 0.56 & 524,635 & 4281 \\
\hline $\begin{array}{l}\mathrm{Ca} 12- \\
\mathrm{Be}\end{array}$ & 16.52 & 2.35 & 16.22 & 0.85 & 598,075 & 5618 \\
\hline $\begin{array}{l}\text { Ca13- } \\
\mathrm{Be}\end{array}$ & 18.36 & 2.35 & 18.12 & 0.81 & 605,462 & 6350 \\
\hline $\begin{array}{l}\text { Ca14- } \\
\mathrm{Be}\end{array}$ & 16.45 & 2.96 & 15.96 & 0.74 & 635,153 & 5637 \\
\hline $\begin{array}{l}\mathrm{Ca} 15- \\
\mathrm{Be}\end{array}$ & 18.24 & 2.12 & 17.47 & 0.69 & 563,508 & 4865 \\
\hline $\begin{array}{l}\text { Ca16- } \\
\mathrm{Be}\end{array}$ & 14.65 & 2.1 & 13.35 & 0.54 & 532,864 & 5026 \\
\hline $\begin{array}{l}\text { Ca17- } \\
\mathrm{Be}\end{array}$ & 20.35 & 2.3 & 20.01 & 0.92 & 478,652 & 6258 \\
\hline $\begin{array}{l}\mathrm{Ca} 18- \\
\mathrm{Be}\end{array}$ & 16.25 & 1.6 & 15.87 & 0.68 & 515,728 & 6351 \\
\hline $\begin{array}{l}\mathrm{Ca} 19- \\
\mathrm{Be}\end{array}$ & 19.34 & 2.25 & 18.65 & 1.14 & 496,254 & 5904 \\
\hline $\begin{array}{l}\mathrm{Ca} 20- \\
\mathrm{Be}\end{array}$ & 21.34 & 1.35 & 20.04 & 0.74 & 630,542 & 6743 \\
\hline $\begin{array}{l}\mathrm{Ca} 21- \\
\mathrm{Ma}\end{array}$ & 17.98 & 1.82 & 17.13 & 0.86 & 563,435 & 6450 \\
\hline $\begin{array}{l}\mathrm{Ca} 22- \\
\mathrm{Ma}\end{array}$ & 18.27 & 2.47 & 17.62 & 0.54 & 635,028 & 6501 \\
\hline $\begin{array}{l}\mathrm{Ca} 23- \\
\mathrm{Ma}\end{array}$ & 19.12 & 2.35 & 18.97 & 0.98 & 543,759 & 5642 \\
\hline $\begin{array}{l}\mathrm{Ca} 24- \\
\mathrm{Ma}\end{array}$ & 14.22 & 1.85 & 13.35 & 0.87 & 431,078 & 4677 \\
\hline $\begin{array}{l}\mathrm{Ca} 25- \\
\mathrm{Ma}\end{array}$ & 16.35 & 1.5 & 15.25 & 1.02 & 486,381 & 3862 \\
\hline $\begin{array}{l}\mathrm{Ca} 26- \\
\mathrm{Ma}\end{array}$ & 19.28 & 1.25 & 18.26 & 0.69 & 658,582 & 5562 \\
\hline
\end{tabular}




\begin{tabular}{|lllllll|}
\hline Name & $\begin{array}{l}\text { Raw reads } \\
\text { (million) }\end{array}$ & $\begin{array}{l}\text { Raw nucleotides } \\
\text { (Gb) }\end{array}$ & $\begin{array}{l}\text { Clean reads } \\
\text { (million) }\end{array}$ & $\begin{array}{l}\text { Genome } \\
\text { Coverage }\end{array}$ & $\begin{array}{l}\text { Unique } \\
\text { reads }\end{array}$ & $\begin{array}{l}\text { Reads containing } \\
\text { SSRs }\end{array}$ \\
\hline $\begin{array}{l}\text { Ca27- } \\
\text { Ma }\end{array}$ & 18.47 & 0.93 & 17.98 & 0.94 & 546,865 & 5048 \\
\hline $\begin{array}{l}\text { Ca28- } \\
\text { Ma }\end{array}$ & 19.25 & 2.84 & 19.1 & 0.75 & 865,146 & 6433 \\
\hline $\begin{array}{l}\text { Ca29- } \\
\text { Ma }\end{array}$ & 16.1 & 2.37 & 15.88 & 0.64 & 561,353 & 5031 \\
\hline $\begin{array}{l}\text { Ca30- } \\
\text { Ma }\end{array}$ & 22.38 & 1.81 & 21.74 & 0.99 & 765,095 & 5462 \\
\hline avg & 16.52 & 1.85 & 15.72 & 0.73 & 575,336 & 5357 \\
\hline Max & 22.38 & 2.96 & 21.74 & 1.14 & 865,146 & 6501 \\
\hline Min & 11.4 & 0.93 & 10.81 & 0.52 & 431,078 & 3268 \\
\hline Total & 495.72 & 55.61 & 471.75 & 22.17 & $17,260,075$ & 160,715 \\
\hline
\end{tabular}

Figures 


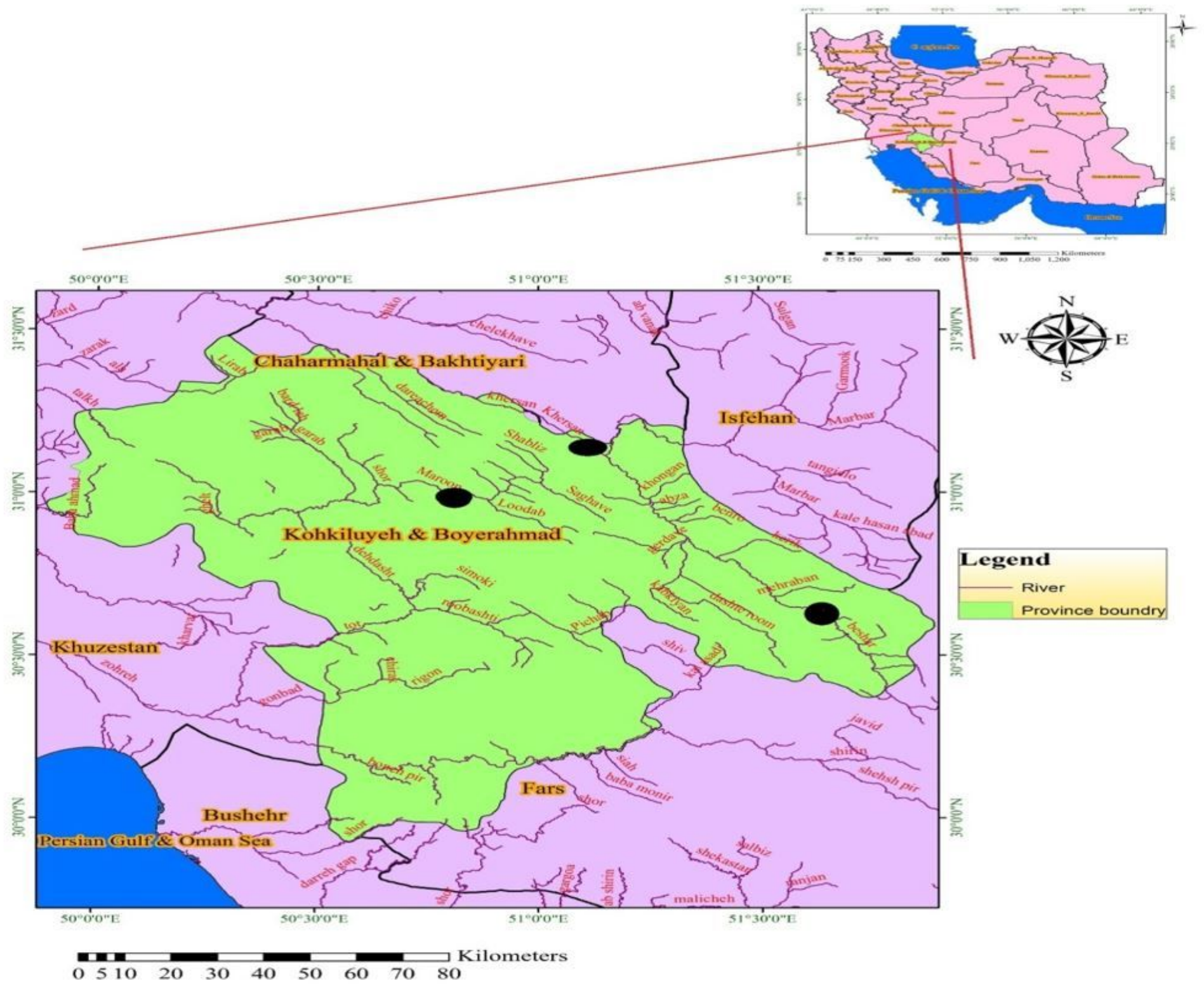

Figure 1

Map depicting the locations of the three populations of Capoeta aculeata used in the study. Detailed information about the sites can be found in Table 1. Note: The designations employed and the presentation of the material on this map do not imply the expression of any opinion whatsoever on the part of Research Square concerning the legal status of any country, territory, city or area or of its authorities, or concerning the delimitation of its frontiers or boundaries. This map has been provided by the authors. 
Genotyping by sequence

471752360 clean reads

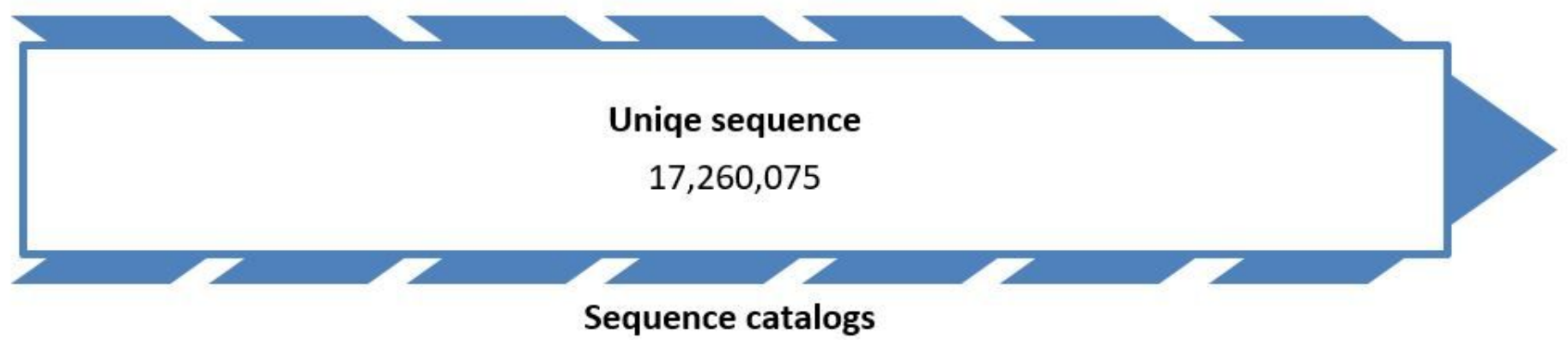

2758956

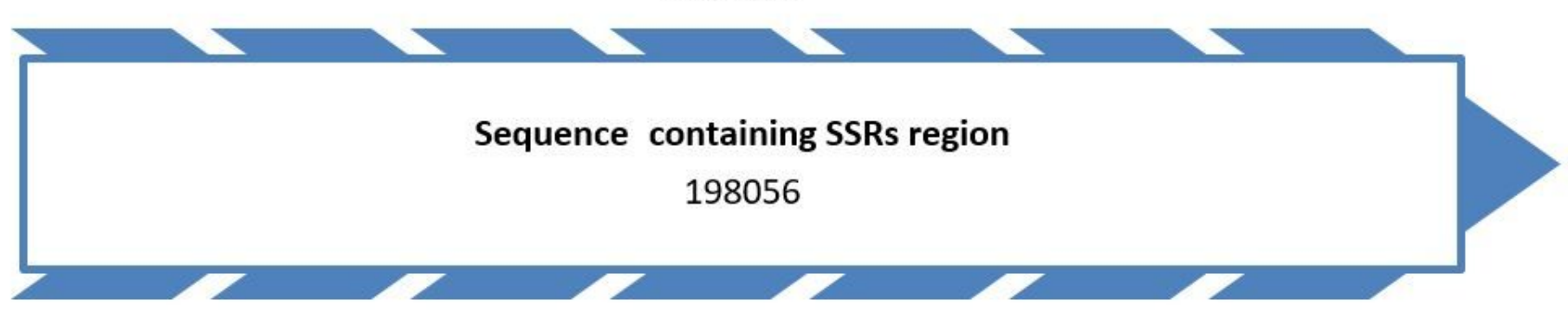

All sample read alignment with sequence containing SSRs region

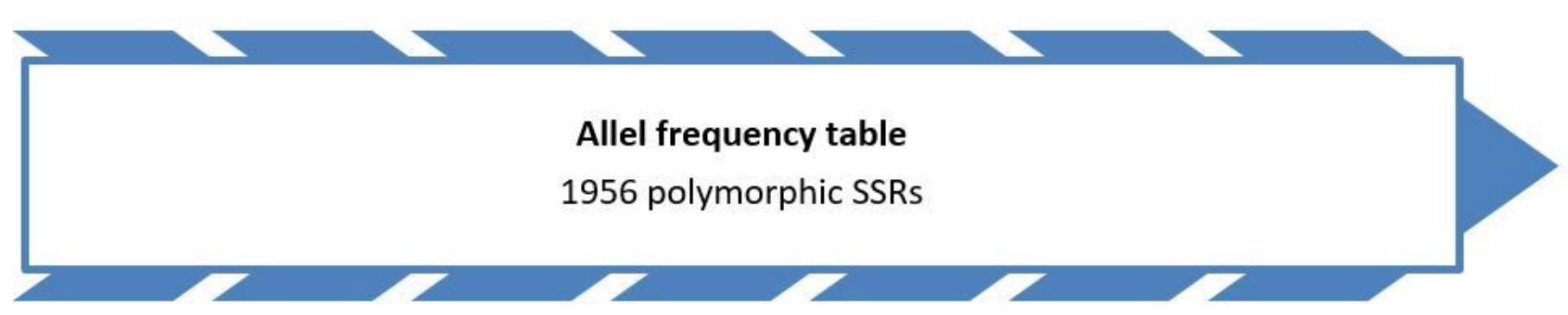

Figure 2

Bioinformatic workflow for GBS-based SSR sequence identification 